\title{
A study on the impact of stock market fluctuations on the operating performance of the listed companies in energy conservation and
}

\author{
environmental protection industry
}

Di Zhang, Yingming Zhu*

School of Economics and Management, Nanjing University of Science and Technology,

China

*Corresponding author: Yingming Zhu, Professor, zhuyingming@njust.edu.cn

\begin{abstract}
With the problem of environment pollution and resource shortage becoming more and more serious, the development of energy conservation and environmental protection industry is booming. In order to put forward some suggestions on the development of energy conservation and environmental protection industry, this paper studies the influence of stock market fluctuations on the operating performance of the listed companies of energy conservation and environmental protection industry in China. This article uses the panel model to test empirically the annual data of 51 companies of energy conservation and environmental protection industry between 2006 and 2015.
\end{abstract}

Key words: Stock market fluctuation; Energy conservation and environmental protection industry; Operating performance

\section{Introduction}

\subsection{Background}

Since the 1990s, China's stock market, as the mainstay of the capital market, has developed at a remarkable speed, affected by the flourishing real economy. Now China's stock market acts well as a barometer of national economy. Energy conservation and environmental protection industry is a strategic emerging industry, and the government provides increasing investment to support its development in order to promote industrial upgrading and economic performance. Therefore, it's important to analysis the impact of the stock market fluctuation on the operating performance of the listed companies in energy conservation and environmental protection industry for the development of this industry. 


\subsection{Literature}

The existing literature mainly focuses on the study on the impact of stock market fluctuations on the performance of the financial industry.

With the diversification of business, banks are increasingly involved in securities business; the instability of the banks is closely related with the sharp fluctuations in the stock market. ${ }^{1}$ The rise of stock prices will affect the bank's direct investment business, thereby affecting its operating performance. ${ }^{2}$ The sharp fluctuations of stock market will have a direct impact on banks because of the close relationship between the stock market and banks, therefore, commercial banks should improve operating performance taking advantage of benefits of this close relationship and prevent the crisis resulting from disadvantages of this relationship. ${ }^{3}$

The operating performance of non-financial listed companies is affected by various factors, such as financial leverage, capital structure, market structure, management and so on; ${ }^{4-5}$ the interest rate also has an impact on the company's operating performance because it can directly affect the company's financial leverage and capital structure. ${ }^{6}$ Instead of the direct impact of stock market fluctuations on the operating performance of non-financial listed companies, researches focus on the impact of stock market fluctuations on the capital structure and the interest rate. Fluctuations of stock prices can cause companies to deviate from the target capital structure. ${ }^{7}$ Changes in common stock prices of list companies will make the financial leverage change correspondingly, affecting the capital structure. ${ }^{8}$ Stock market fluctuations will be passed to the interest rate, so the interest rate changes will result in the capital structure adjustment. ${ }^{9}$ Overall,the stock market fluctuations influence the operating performance of listed companies, with the capital structure as a medium.

\section{Experimental}

\subsection{Hypotheses}

Comprehensive operating performance evaluation of listed companies can be constructed in aspects of profitability, solvency, operating capacity and growth ability.

Stock market fluctuations affect the enterprise's sales through the wealth effect. When the stock prices rise, the investors' expected income will rise. The sales growth of listed companies can be expected, considering, also, the strong macroeconomic trends. In addition, assuming the debt unchanged, stock market fluctuations will lead to changes of net asset values of listed companies.Net asset is the source of corporate profits, that is to say, the value 
of net assets indicates the profitability of list companies.

Based on the above theoretical analysis, the following hypothesis is put forward:

H1: There is a significant positive (negative) correlation between the rise (fall) of stock market and corporate profitability.

The impact of stock market fluctuations on company's solvency is reflected in that: stock market fluctuations affect the cost of indirect financing through the balance sheet effect. When the stock market is in good shape, firms can choose more direct financing and reduce the indirect financing of bank loans, lowering agency costs. Therefore, the rise of stock price can reduce corporate financing costs and improve its solvency. But the impact is still uncertain, because in other ways, this is not the case, especially when it refers to the interest rate. If the stock market is in an uptrend, on the one hand the interest rate may rise because the monetary authorities will tight monetary policy in order to squeeze out the stock market bubble; on the other hand, the interest rate will decrease because of reduced demands for money resulting from a large amount of stock investments. The change in the interest rate will be set by the competition between two forces.

Based on the above theoretical analysis, the following hypotheses are put forward:

H2a: There is a significant positive (negative) correlation between the rise (fall) of stock market and corporate solvency.

H2b: There is a significant negative (positive) correlation between the rise (fall) of stock market and corporate solvency.

Stock market fluctuations will promote the sale of enterprises through the wealth effect, thereby speeding up the turnover of corporate inventories. In addition, the stock market fluctuations will also affect the macroeconomic development through the wealth effect, liquidity effect and financial accelerator effect. Optimistic economic trends help listed companies recover the receivables from enterprises that they have economic transactions with. Excellent conditions of inventory turnover and capital turnover show the outstanding operating capacity of listed companies.

Based on the above theoretical analysis, the following hypothesis is put forward:

H3: There is a significant positive (negative) correlation between the rise (fall) of stock market and corporate operating capacity.

Stock market fluctuations will affect the investment situations of listed companies through the Tobin's Q effect. Higher stock market is conducive to listed companies for direct financing. Abundant financial resources always mean an upturn in investment spending, which to a 
certain extent, can accelerate the accumulation of capital and improve the output of products in the future. These all indicate developing potential of the listed companies. In addition, the stock market fluctuations will also affect the value of corporate net assets, which are the basis of corporate profits. These all reflect the enterprise has excellent growth ability.

Based on the above theoretical analysis, the following hypothesis is put forward:

H4: There is a significant positive (negative) correlation between the rise (fall) of stock market and corporate growth ability.

\subsection{Samples}

In order to study the effect of stock market fluctuations on the performance of energy conservation and environmental protection industry, this paper adopts panel data to carry out the empirical analysis, including data about the profitability, solvency, operating capacity and growth ability of 51 energy conservation and environmental protection listed companies in 2006 - 2015.Since the listed companies selected in this paper are from both the Shanghai Stock Exchange and the Shenzhen Stock Exchange, CSI 300 Index is taken to represent stock market price. Relevant data about listed companies is from the annual reports of listed companies and the database of TongHuaShun, data about CSI 300 Index is from Sina finance and economics, and other data is from the State Statistics Bureau.

\subsection{Variables}

Table 1 - Descriptions of variables

\begin{tabular}{|c|c|c|c|}
\hline \multicolumn{3}{|c|}{ Variables } & Descriptions \\
\hline \multirow{4}{*}{$\begin{array}{c}\text { Dependent } \\
\text { variable }\end{array}$} & profitability & ROE & return on equity \\
\hline & solvency & SOL & tangible assets/ interest-bearing debts \\
\hline & operating capacity & $\mathrm{BC}$ & business cycle \\
\hline & growth ability & NA & net assets \\
\hline $\begin{array}{c}\text { Independent } \\
\text { variable }\end{array}$ & $\begin{array}{l}\text { stock market } \\
\text { fluctuations }\end{array}$ & SMF & fluctuations of CSI 300 Index \\
\hline \multirow{3}{*}{$\begin{array}{l}\text { Control } \\
\text { variable }\end{array}$} & size & SIZE & the size of the company \\
\hline & CPI index & CPI & CPI \\
\hline & GDP index & GDPG & the growth rate of GDP \\
\hline
\end{tabular}

The variables selected in this paper include three categories: dependent variables, independent variables and control variables. There are four kinds of dependent variables that measure the 
company's profitability, solvency, operating capacity and growth ability. The independent variable is the stock market fluctuation. The control variables are the size of companies, the CPI index and the growth rate of GDP. Concrete conditions are shown in Table 1.

\subsection{Model specifications}

There are three main models of panel data, including the mixed model, the fixed effect model and the random effect model, and their respective equations are as follows:

$$
\begin{aligned}
& Y_{i t}=\beta_{1}+\sum_{k=2}^{K} \beta_{k} X_{k i t}+u_{i t} \\
& Y_{i t}=\delta+\lambda_{i}+\sum_{k=2}^{K} \beta_{k} X_{k i t}+u_{i t} \\
& Y_{i t}=\beta_{1}+\sum_{k=2}^{K} \beta_{k} X_{k i t}+u_{i}+v_{t}+W_{i t}
\end{aligned}
$$

In our empirical analysis, which model is to be selected is determined by the results of the F-test and the Hausman test. Before regression analysis,t he data should be checked by the unit root test and the co-integration test to prevent the occurrence of spurious regression.

\section{Results and Discussion}

\subsection{Unit root test}

Among all variables, three fail to pass the unit root test, the series is not stationary. Therefore, it requires a first order difference for each variable to determine its single order, as shown in Table 2 below.

Table 2 - Results of unit root test

\begin{tabular}{c|cc|cc|cc|cc}
\hline \multirow{2}{*}{} & \multicolumn{2}{|c|}{ LLC } & \multicolumn{2}{c|}{ IPS } & \multicolumn{2}{c}{ ADF-Fisher } & \multicolumn{2}{c}{ PP-Fisher } \\
& Statistic & Prob.** & Statistic & Prob.** & Statistic & Prob.** & Statistic & Prob.** \\
\hline ROE & -27.9930 & 0.0000 & -14.0668 & 0.0000 & 406.2670 & 0.0000 & 541.7030 & 0.0000 \\
SOL & -1245.0900 & 0.0000 & -136.3750 & 0.0000 & 306.6520 & 0.0000 & 374.2900 & 0.0000 \\
BC & -886.4020 & 0.0000 & -86.0121 & 0.0000 & 284.3520 & 0.0000 & 306.1400 & 0.0000 \\
NA & -25.5623 & 0.0000 & -13.9046 & 0.0000 & 401.0030 & 0.0000 & 639.2910 & 0.0000 \\
SMF & -29.3852 & 0.0000 & -18.2339 & 0.0000 & 514.1770 & 0.0000 & 658.0680 & 0.0000 \\
SIZE & -15.9024 & 0.0000 & -6.3361 & 0.0000 & 229.2170 & 0.0000 & 247.0960 & 0.0000 \\
CPI & -138.3500 & 0.0000 & -66.0013 & 0.0000 & 1162.5100 & 0.0000 & 537.0730 & 0.0000 \\
GDPG & -48.0158 & 0.0000 & -20.9951 & 0.0000 & 569.2030 & 0.0000 & 781.9410 & 0.0000 \\
\hline
\end{tabular}


It can be seen from Table 2 that the first-order differences of all variables pass the unit root test, the first-order differences of all variables are stationary, that is to say, ROE, SOL, BC, NA, SMF,SIZE,CPI and GDPG are integrated of order 1.Based on this result, co-integration test can be taken.

\subsection{Co-integration test}

The co-integration test is a way to test the long-term equilibrium relationship of variables. From the results of Table 3, we can see each variable rejects the original hypothesis, and there is a co-integration relationship between the variables. In this case, regression analysis can be carried out with the original data, and there doesn't exist spurious regression.

Table 3 - Results of co-integration test

\begin{tabular}{c|c|c|c}
\hline \multirow{2}{*}{ SMF and ROE } & Hypothesis & Trace Statistic $(\mathrm{p})$ & Max-Eigen Statistic $(\mathrm{p})$ \\
\cline { 2 - 4 } & none & $924.6(0.0000)$ & $769.4(0.0000)$ \\
\hline \multirow{2}{*}{ SMF and SLO } & at most 1 & $427.1(0.0000)$ & $427.1(0.0000)$ \\
\cline { 2 - 4 } & none & $797.3(0.0000)$ & $676.3(0.0000)$ \\
\hline \multirow{2}{*}{ SMF and BC } & at most 1 & $353.8(0.0000)$ & $353.8(0.0000)$ \\
\cline { 2 - 4 } & none & $840(0.0000)$ & $720.1(0.0000)$ \\
\hline \multirow{2}{*}{ SMF and NA } & at most 1 & $376(0.0000)$ & $376(0.0000)$ \\
\cline { 2 - 4 } & none & $791.5(0.0000)$ & $379.8(0.0000)$ \\
\hline
\end{tabular}

\subsection{Regression results}

Regression analysis can be carried out, after selecting the model through F-test and Hausman test, and regression results are shown in Table3.3 below.

The regression results about the profitability of listed companies are shown in column (1) of Table 4.It can be seen that the regression has a low degree of goodness of fit. The D.W.value, which is about 1.82,implies there does not exist auto correlation in the data. The impact of stock market fluctuations on the profitability of the company is significant, and the coefficient is positive, confirming the $\mathrm{H} 1$.

The regression results about the solvency of listed companies are shown in column (2) of Table 4.The goodness of fit of the regression is low. The D.W.vale is 1.98,suggesting there does not exist auto correlation in the data. The impact of stock market fluctuations on the solvency of the company is significant, and the coefficient is positive, confirming the H2a. 
Stock market fluctuations have a positive impact on the solvency of energy conservation environmental protection industry listed companies. In the previous analysis, complex factors that caused by the stock market fluctuations, affect the solvency. Among these factors, some are positive, and others are negative. From the final results, we can know positive factors defeat the negative ones.

Table 4 -Regression results

\begin{tabular}{|c|c|c|c|c|}
\hline \multirow{3}{*}{ Variables } & profitability & solvency & operating capacity & growth ability \\
\hline & ROE & SOL & $\mathrm{BC}$ & NA \\
\hline & (1) & (2) & (3) & (4) \\
\hline $\mathrm{C}$ & $-101.5301^{* *}$ & -128.9712 & 562.3337 & -2971.7850 \\
\hline $\mathrm{SMF}$ & $0.0306^{* *}$ & $0.1281^{* *}$ & 1.5650 & $1.3613^{*}$ \\
\hline SIZE & 0.5627 & $-11.5201 * * *$ & -47.3470 & 14.7378 \\
\hline CPI & -0.2809 & $-4.2759 * * *$ & 28.0732 & $-38.5869 *$ \\
\hline GDPG & $0.9938 * *$ & $3.1089 * *$ & 0.6078 & 29.9588 \\
\hline R-squared & 0.0218 & 0.1943 & 0.0087 & 0.0089 \\
\hline F-statistic & 2.81318 & 2.0142 & 1.1123 & 1.1280 \\
\hline D-W stat & 1.8188 & 1.9821 & 0.4257 & 2.1802 \\
\hline
\end{tabular}

Notes: $* * *, * * *$ respectively statistically significant at the $10 \%, 5 \%, 1 \%$ level.

The regression results about the operating capacity of listed companies are shown in column (3) of Table 4.The goodness of fit of the regression is terribly low. The impact of stock market fluctuations on the operating capacity of the company is not significant even at the significance level of $10 \%$,and $\mathrm{H} 3$ is not confirmed. Maybe the slight impact of stock market fluctuations on the operating capacity can be ignored, compared with the effects of enterprise's business policy, financial policy and so on.

The regression results about the growth ability of listed companies are shown in column (4) of Table 4.It can be seen that the regression has a low degree of goodness of fit. The D.W.value is 2.18,implying there does not exist auto correlation in the data. The impact of stock market fluctuations on the growth ability of the company is significant, and the coefficient is positive, confirming the $\mathrm{H} 4$.

\section{Conclusions}

This paper studies the impact of stock market fluctuations on the performance of listed companies in energy conservation and environmental protection industry. Through the 
theoretical and empirical analysis, this paper has the following conclusions: stock market fluctuations have a positive impact on the profitability, solvency and growth ability of listed companies in the energy conservation and environmental protection industry; stock market fluctuations have no impact on the operating capacity of listed companies in the energy conservation and environmental protection industry.

\section{References}

1. J.S. Duan,Theoretical and Empirical Analysis on the Impact of Stock Price Fluctuation on Bank Stability,Shanghai Finance.6 (2006) 8-11.

2. C.H. Shan,The Influence Mechanism of Stock Price Fluctuation on Banking Fragility,Journal of Shijiazhuang University of Economics.31 (2008) 11-15.

3. M.F. Lu,Stock Market and Crisis Management of Commercial Bank,Research on Financial and Economic Issues.8 (2008) 119-123.

4. D. Margaritisa,M. Psillaki,Capital structure, equity ownership and firm performance, Journal of Banking \& Finance.34 (2010): 621-632.

5. A.N. Berger, E.B.Di Patti,Capital structure and firm performance: A new approach to testing agency theory and an application to the banking industry,Journal of Banking \& Finance.30 (2006) 1065-1102.

6. T.Y. Zhang,C. Xie,F. Gao,An Empirical Study on the Impact of Interest Rate on the Capital Structure of Listed Companies,Journal of Financial Research. 12 (2007) 179185.

7. Z.Q. Wang,Y.X. Hong,Empirical Research on the Long-term Dynamic Adjustment of Capital Structure,Accounting Research.6 (2009) 50-57.

8. S. Titman, R. Wessels, The determinants of capital structure choice,The Journal of finance.43 (1988) 1-19.

9. Z.D. Xiong,M. Xie,An Empirical Study on the Volatility Spillovers Effect between Chinese Interest Rate and Stock Markets,The Theory and Practice of Finance and Economics.28 (2007) 46-50. 